Jurnal Keperawatan Padjadjaran

ISSN 2338-5324 (print)

ISSN 2442-7276 (online)

Online di http://jkp.fkep.unpad.ac.id

DOI : $10.24198 / \mathrm{jkp}$

\title{
Correlation between Spiritual Well-Being and Level of Fatigue among Patients Suffering from Breast Cancer
}

Received: 09-01-2021 Revised: 01-04-2021 Accepted: 05-04-2021

\begin{abstract}
Cancer-related fatigue has been shown to be a significant side effect that influences a person's wellbeing, during treatment, and after treatment. It is recorded that cancer patients have also been shown experiencing spiritual distress. The study aims to determine the connection between spiritual well-being and cancer-related fatigue among patients suffering from breast cancer during chemotherapy treatment. 112 patients who were undergoing chemotherapy treatment were recruited in this study using a correlational design. The instruments used in assessing spiritual well-being and fatigue are Functional Assessment of Chronic Illness Therapy - Spirituality (FACIT-Sp) and FACIT-Fatigue Scales. Data were analyzed using the Spearman Correlation analysis. Mean spiritual well-being score was $35.91(\mathrm{SD}=6.89)$, and the mean fatigue score was $33.04(\mathrm{SD}=9.58)$. There were a moderate and significant correlation between fatigue scores and spiritual well-being $(r=.364, p<0.001)$. Breast cancer patients who had higher spiritual well-being that means they would alleviate fatigue symptoms. Therefore, nurses should consider that increasing spiritual well-being would reduce fatigue and vice versa.
\end{abstract}

Keywords: Breast cancer, chemotherapy, fatigue, spiritual well-being, treatment. 
Maria Komariah: Correlation between Spiritual Well-Being and Level of Fatigue among Patients

\section{Introduction}

Breast cancer patients with a complicated stage suffer from the threat of death, uncertainty, and various symptoms because of the disease and its treatment (fatigue, pain, weakness, dry mouth, constipation, decreased energy, taste change, and depression) (Sari, 2019). All these symptoms are reported to impact on a cancer patient's functional status and wellbeing status (Dodd, Cho, Cooper, \& Miaskowski, 2010). Spiritual distress can occur due to suffering of being terminally ill (Lestari, Nuraeni, \& Setyorini, 2018; Loh, 2004; Villagomeza, 2005). Patients with spiritual distress have stated that they see the meaning of their life, their illness, death and suffering as a punishment. Such patients may well be unstable emotionally, sad, withdrawn, apathetic, and in denial (Komariah, Adriani, Indrayani, \& Gartika, 2020; Loh, 2004). Having a complicated breast cancer diagnosis, or other life-threatening conditions, could change a person's perception about life (Komariah, Adriani, et al., 2020; ManningWalsh, 2005), and put such an individual in danger for altered spiritual well-being that changes within the person's wellness, symptoms of their disease and treatment.

Moreover, many studies have reported that the impact of advanced breast cancer patients enduring cancer-related-fatigue (CRF) is extensive (Hsieh et al., 2019; Kinkead et al., 2018; Zimmaro et al., 2019)). Most cancer patients reside with CRF because of their cancer treatment and diagnosis. A number of advanced breast cancer patients might have physical and psychological comorbidities that may augment fatigue and complicate its management (Bower, 2008; Loh, 2004). Fatigue symptoms are also the common side effect of patients who are admitted to the chemotherapy unit in Indonesian hospitals (Nurhasanah, 2014). According to the National Comprehensive Cancer Network (2009), fatigue experienced by cancer patients is a state of persisting weakness, where the sensations felt are very personal, as well as the type of fatigue that is not relieved by rest. Fatigue can affect patients in an immensely negative way. It impacts on the spiritual well-being due to feelings of uncertainty, helplessness and fears about death. Thus, it results in patients experiencing set-backs in a chemotherapy treatment schedule (Borneman, Irish, Sidhu, Koczywas, \& Cristea, 2014).

Fatigue is a general term used to describe the different feelings with a diversity of terminologies indicating alleviated either physical, mental, emotional, or social capacity, and it is also indicate distress (Lewis, Salins, Rao, \& Kadam, 2014). Fatigue is the paramount prevailing symptom among cancer patients receiving radiation therapy and cytotoxic chemotherapy. CRF is an experience subjective to the individual cancer patient, and it is affected by various determinants, such as physical, psychological, and spiritual factors. Physically, fatigue can result from the direct effects of cancer, cancer-related symptoms, and therapy effects; psychologically, fatigue can result from the emotional distress stimulated by cancer and its effects; and spiritually, fatigue can result from the spiritual dryness due to cancer. Not only a few cancer patients feel like religion or spirituality becomes their comfort, which in several occasions, it is associated to positive psychological result and depletion in distressful symptoms (Lewis et al., 2014). Spirituality is said to higher quality of life because it provides social support, enhances the connection with the spouse, and provides interpretation, and decreases self-focus and anxiety (Garssen, Uwland-Sikkema, \& Visser, 2015). Studies also showed that, in contrast to those who only involved less in spiritual activities, patients with certain illness but holding a great principle to spirituality seem to have a finer adaptation, undergo the higher level of well-being and quality of life, and encounter lower degree of distress (Garssen et al., 2015). This study examines spiritual well-being and fatigue in patients suffering from breast cancer who undergo chemotherapy and determines presence of interconnection between fatigue and spiritual well-being in breast cancer stage III.

Concept of spiritual well-being is defined as an expression (Wilding, Muir-Cochrane, \& May, 2006), a person's mental spiritual measure, which is built by two domains, namely religion and spirituality. Clay, Talley, and Young (2010) defined spiritual wellbeing as the capability to foster expectation 
and take interpretation from life experiences and feel the life force in dealing with self, God, family, and life elements that help empower themselves. Spiritual well-being is instrumental in health and healing process. According to Ellison (2006), the spiritual well-being is defined as the process of elaborating the nature of the dynamic bond between the person and the Creator, whose harmonious relationship is dependent on the deliberate self-development, usually on the basis of the appropriateness between experiencing a meaningful life, the goals and values of personal life. This self-development is also made as a personal challenge, done by meditation or contemplation leading to an inner state of happiness.

Gomez and Fisher (2003) explain spiritual well-being as a concept describing the innate state, with an element of motivation or inner drive to find the purpose of life, which is naturally dynamic and subjective. Further, it is focused on something distinctive, which then is believed to be the truth. Spiritual wellbeing contains a real act of dealing with the essence of existence, certain inner experience and belief. All of them provide a goal, meaning and values for a quality of life, e.g., by giving thanks to God, loving others, and learning from previous life experiences (Gomez \& Fisher, 2003). Spiritual well-being has some components, such as, feelings of harmony, peace, the meaning and purpose of life, and the power of faith (Bredle, Salsman, Debb, Arnold, \& Cella, 2011). Faith is an important aspect that contributes to the spiritual wellbeing of the person. Various studies have pointed out that faith, especially faith in God, helps the cancer patient to live well amidst the pain and suffering from cancer. There are many ways in which the persons with advanced breast cancer express their faith in God and how belief in God helps them to cope with cancer. Some of them express faith in God through prayers asking for strength and spiritual well-being (Komariah, Hatthakit, \& Boonyoung, 2020).

Regarding sense of spiritual well-being, in a Muslim country, Ahmad, binti Muhammad, and Abdullah (2011) used a qualitative study to explore religious practice and spirituality and coping among three Malay Muslim females with advanced breast cancer. They figured that life-threatening diseases, for instance breast cancer, can be a spiritual encounter and a deeply emotional experience as they cope and find the way toward healing. Therefore, it can be concluded that spiritual well-being in this study reflects the extent to which patients live in harmony with regard to the meaning, purpose, and values of life amidst suffering from cancer (Komariah, Hatthakit, et al., 2020) This component is important in the treatment process of cancer to increase hopeful health results. In Indonesia, two studies tested about the level of spiritual well-being among breast cancer patients, they stated that moderate level of spiritual wellbeing among all cancer survivors (Suara, Mardiyono, \& Anggorowati, 2017) but poor level of spiritual well-being among breast cancer patients undergoing chemotherapy (Wahyuningsih, Sofro, \& Dwidiyanti, 2019).

Additionally, several studies have shown that $80 \%$ to $90 \%$ of patients suffering from breast cancer experiencing fatigues during undergoing chemotherapy (Schmidt et al., 2015). Fatigue symptoms were consistently documented for above $50 \%$ of various types of cancer therapy (Naraphong, Lane, Schafer, Whitmer, \& Wilson, 2015). Research study regarding fatigue among breast cancer in Indonesia reported that majority of the breast cancer patients developed fatigue in moderate level $(50 \%)$ and , severed level $61(42.4 \%)$ whereas only few $(7.6 \%)$ of them had mild level of fatigue (Dahlia, Karim, \& Damanik, 2019).

The chemotherapy regimen can cause fatigue; for instant, breast cancer patients who received 5Fluoroacil, Doxorubicin and Cyclophosphamide chemotherapy had muscle weakness caused by stimulation cell oxidative reactions from peroxidation lipids and protein carbonyl. They are released from doxorubicin and delivered to $\mathrm{C} 2 \mathrm{C} 12$ myotubes which will activate caspases enzymes and proteolysis and which result in muscle cell apoptosis. It causes reduced muscle mass and contraction ability as the originator of the complaint of fatigue (Gilliam \& St. Clair, 2011). When cancer threatens the meaning of an individual life, religion and spirituality are often important coping strategies (Lewis et al., 2014). Fatigue can impact all dimensions of a person's life 
including physical, psychological, social and spiritual well-being. This study assesses the correlation between spiritual well-being and level of fatigue among patients suffering from breast cancer undergoing chemotherapy treatment.

\section{Method}

This is a cross sectional study appraising fatigue and spiritual well-being in breast cancer patients undergoing chemotherapy. A total of 112 breast cancer selected using consecutive sampling who receiving chemotherapy between January and June 2018 at Chemotherapy unit in a teaching hospital, if they satisfied the selection criteria and gave consent to participate. Inclusion criteria consisted of aged more than 18 years old, have a diagnosis of stage III newly or recurrently, cognitively intact without mental illness. The participants who satisfying the selection criteria and willingness to participate in this study imparted the following selfreport questionnaires to examine fatigue and spiritual well-being. Fatigue and spiritual well being were assessed using the functional assessment of chronic illness therapy (FACIT) measurement system, which is a collection of QOL questionnaires aimed to the management of chronic illness such as cancer. The tools are validated and permission for use wasobtained following registration (www.facit.org). It is a cross sectional study where the patients were screened at a certain point of time during their active cancer chemotherapy medicaments. The researcher did the screening after obtaining patients informed consent for the same. The study was authorized by Intuitional review board of the Faculty of Nursng, Prince of Songkla University, Thailand, number 2017 NSt-Qn 054.

The Functional Assessment of Chronic Illness Therapy (Fatigue) (FACIT-F) was utilized to estimate the level of fatigue. The questionnaire consists of 13 items in the form of statements. The total score of FACIT-F should be in the range of $0-52$. If the score was $<30$, this indicates that the patient is having severe fatigue. The higher score of FACIT-F demonstrates a low-stage of fatigue, whereas a lower outcome of FACIT-F indicates a high level of fatigue. The original instrument showed reliability of alpha Cronbach 0.95 and the validity test 0.88 (Yellen, Cella, Webster, Blendowski, \& Kaplan, 1997) while the Indonesian version reported 0.88 for reliability test and alpha Cronbach .95 (Aisyah, 2017).

The Functional Assessment of Chronic Illness Therapy (Spiritual) (FACIT-Sp). The measurement of spiritual well-being was assessed by the FACIT-Sp which was established by Cella et al. (1993). The FACIT-Sp is a 12-item scale with 2 subscales (meaning/peace and faith); 8 items of meaning/peace (items $1,2,3,4,5,6,7$, 8 ), and 4 items of faith (items $9,10,11,12$ ). Using Likert-type scales (absolutely not $=0$, a bit $=1$, slightly $=2$, quite a lot $=3$, very much $=4$ ). A higher score indicates a higher stage of spiritual well-being. Reliability was announced for the total FACIT-Sp and subscales. The internal consistency varied from 0.81 to 0.88 . The possible scores of the FACIT-Sp stretched from $0-48$. The instrument had a Cronbach's alpha coefficient of .87 .

Data was registered in Microsoft excel and evaluated using statistical package for social science version 16 (IBM corporation). A Bivariate Spearman's correlation analysis was carried out between independent and dependent variables.

\section{Results}

A total of 112 breast cancer patients undergoing chemotherapy were included in the study. Average age of patients who participated in the study was $47.2 \pm 8.2$ years. Among the patients studied 32.1\% had stage IIIa, $60.7 \%$ had stage IIIb, and $7.2 \%$ had stage IIIc illness (Table 1). Based on the demographic data crosstab analysis, the study resulted that only the education had a significant relationship with spiritual well-being. While the occupation and family income had significant relationship with fatigue (Table 2).

Bivariate relationships were chosen between dependent and independent variables using Spearman's correlation analysis. There 
Maria Komariah: Correlation between Spiritual Well-Being and Level of Fatigue among Patients

was a notable connection between fatigue

(Table 3).

scores with spiritual well being $(\mathrm{P}<0.001)$,

Table 1 General Data on the Breast Cancer Patients Undergoing Chemotherapy

\begin{tabular}{|c|c|c|c|}
\hline General Data & Categories & Frequency & Percentage (\%) \\
\hline \multirow[t]{3}{*}{ Age (Year) } & Mean : 47.2 & - & - \\
\hline & $\mathrm{SD}: 8.2$ & - & - \\
\hline & Range : $27-64$ & - & - \\
\hline \multirow[t]{3}{*}{ Education } & Primary & 63 & 56.3 \\
\hline & High School & 41 & 36.6 \\
\hline & University & 8 & 7.1 \\
\hline \multirow[t]{3}{*}{ Marital Status } & Single & 4 & 3.8 \\
\hline & Married & 89 & 79.2 \\
\hline & Widow & 19 & 17 \\
\hline \multirow[t]{3}{*}{ Breast Cancer Staging } & IIIa & 36 & 32.1 \\
\hline & IIIb & 68 & 60.7 \\
\hline & IIIc & 8 & 7.2 \\
\hline \multirow[t]{3}{*}{ Chemotherapy treatment } & FAC & 90 & 80.4 \\
\hline & TAC & 13 & 11.6 \\
\hline & $\mathrm{AC}+$ paclitaxel & 9 & 8.0 \\
\hline \multirow[t]{4}{*}{ Chemotherapy/cycle } & 1 & 42 & 37.5 \\
\hline & 2 & 35 & 31.3 \\
\hline & 3 & 16 & 14.3 \\
\hline & 4 & 19 & 16.9 \\
\hline
\end{tabular}

Tabel 2 Crosstab of Demografic Data, Spiritual Well-Being, and Fatigue

\begin{tabular}{lcc}
\hline \multicolumn{1}{c}{ Demographic data } & Spiritual well-being & Fatigue \\
\hline Education & $0.023^{*}$ & 0.087 \\
Occupation & 0.322 & $0.009^{*}$ \\
Family income & 0.335 & $0.014^{*}$ \\
\hline
\end{tabular}

Chi Square, ${ }^{*} \mathrm{p}<0.05$

Table 3 Means, Standard Deviation and Correlations of Spiritual Well-Being and Fatigue

\begin{tabular}{lccccc}
\hline \multicolumn{1}{c}{ Variables } & $\mathbf{N}$ & Mean Value & SD & Correlation & p \\
\hline Spiritual well-being & 112 & 35.91 & 6.9 &. & \\
Fatigue & 112 & 33.04 & 9.6 & .364 & $0.000^{*}$ \\
\hline
\end{tabular}

\section{Discussion}

The study reported that there is a positive association between spiritual well-being and fatigue; it means that higher spiritual wellbeing would alleviate the fatigue symptoms. In other words, the nurses should consider that by increasing spiritual well-being, it would potentially reduce fatigue and vice versa.

These associations could also mean that spiritual well-being would suggest more connectedness in life that would aid them endear to positive health behaviors such as 
being physically and socially active, going for walks in nature etc., This could give them a purpose and meaning in life and reduce distressful symptoms. Indian study on spiritual well-being in advanced lung cancer showed that there was statistically notable association between spiritual well-being and depression, anxiety, five domains of QOL (fatigue, distress and sadness, mood, work, relationship with others) and enjoyment of life (Kandasamy, Chaturvedi, \& Desai, 2011). Spiritual wellbeing is a complex dynamic state which has a significant impact on clinical outcomes (Komariah \& Ibrahim, 2019; Nuraeni, Nurhidayah, Hidayati, Sari, \& Mirwanti, 2015).

Cancer related fatigue is an immense perception of exhaustion physically, mentally, emotionally which occurs secondary to the disease or due to disease related treatment. It can persevere over time and interferes with daily routines and varies from the tiredness of everyday life, which is normally nonpermanent and diminished by rest. Cancer treatment-related fatigue usually enhances following therapy is done; nevertheless several levels of fatigue may continue for months or years after the treatment. Research specifies that for at least a subset of patients, fatigue may be a conspicuous matter long into survivorship.

According to Lewis et al. (2014), fatigue is a general term used to describe the different feelings with a diversity of terminologies indicating alleviated either physical, mental, emotional, or social capacity, and it is also indicate distress. Fatigue is the most prevailing symptom among cancer patients receiving radiation therapy and cytotoxic chemotherapy. Fatigue symptoms were consistently documented for more than $50 \%$ of various types of cancer therapy (Naraphong et al., 2015).

Health related QOL is the degree to which average or predicted physical, emotional and social wellbeing are influenced by a medical condition or its treatment. Its evaluation demands for attention to several measurements, which include physical concerns (e.g. symptoms), functional ability, family well-being, emotional well-being, spiritual well-being, sexuality and social functioning. Hence in cancer treatment multidimensional, multifaceted approach is quintessential for successful treatment outcomes. In cancer patients, the focal point is usually aimed at treatment and treatment related matters, regulating physical symptoms and comorbidities. Psychological, interpersonal and spiritual well-being matters are seldom evaluated and addressed (Nuraeni, Ibrahim, \& Rizmadewi, 2013; Nuraeni et al., 2015). This study brings out the importance of spiritual well-being in cancer patients and its impact and correlation on fatigue which is one of the most distressing and difficult to treat symptom.

According to Bredle et al. (2011), spiritual well-being has some components, such as, feelings of harmony, peace, the meaning and purpose of life, and the power of faith. Faith is an important aspect that contributes to the spiritual well-being of the person. Various studies have pointed out that faith, especially faith in God, helps the cancer patient to live well amidst the pain and suffering from cancer. There are many ways in which the persons with advanced breast cancer express their faith in God and how belief in God helps them to cope with cancer. Some of them express faith in God through prayers asking for strength and spiritual well-being (Komariah, Hatthakit, et al., 2020).

A study done by Taylor in patients with recurrent cancer with various clinical subtypes showed that the symptom distress was inversely related to spiritual well-being (Taylor, 1993). A similar kind of study done in breast cancer patients showed that lower amount of symptom burden and distress was associated with a better spiritual well-being (Manning-Walsh, 2005). Likewise, demoghraphic data, namely education was significantly related to spiritual well-being, it was inconsistent with previous study indicated that education unrelated to spiritual well-being (Suara et al., 2017). In the present study, occupation and family income were significantly unrelated to spiritual well-being, however they have a significantly related to fatigue.

The findings of this present study support that the nursing interventions to increase the patients' spiritual well-being can reduce their fatigue. So, this research can be used as an evaluation and input to enhance the quality 
Maria Komariah: Correlation between Spiritual Well-Being and Level of Fatigue among Patients

services, particularly the provision of holistic nursing care among patients with breast cancer undergoing chemotherapy.

\section{Conclusion}

To sum up, based on the findings of this study concluded that spiritual well-being has significant relationship with fatigue among persons suffering from breast cancer undergoing chemotherapy. In addition, the education level has significant relationship with spiritual well-being, whereas the occupation and family income have significant relationship with fatigue.

Furthermore, since this study applied convenience sampling and the population included only the Indonesian women with breast cancer undergoing chemotherapy, conducting similar studies using random sampling in other wards and other chronic disease centers is recommended.

\section{References}

Ahmad, F., binti Muhammad, M., \& Abdullah, A. A. (2011). Religion and Spirituality in Coping with Advanced Breast Cancer: Perspectives from Malaysian Muslim Women. Journal of Religion and Health, 50(1), 36-45. https://doi.org/10.1007/ s10943-010-9401-4

Aisyah, P. S. (2017). The Correlation Between Being Deeply Absorbed In Shalat With Adaptation To Illness In Breast Cancer Patients Undergoing Chemotherapy. Proceeding INC 2016, 1(1).

Borneman, T., Irish, T., Sidhu, R., Koczywas, M., \& Cristea, M. (2014). Death awareness, feelings of uncertainty, anad hope in advanced lung cancer patients: can they coexist? International Journal of Palliative Nursing, 20(6). https://doi.org/10.12968/ ijpn.2014.20.6.271

Bower, J. E. (2008). Behavioral Symptoms in Patients With Breast Cancer and Survivors. Journal of Clinical Oncology, 26(5), 768-777. https://doi.org/10.1200/jco.2007.14.3248
Bredle, J. M., Salsman, J. M., Debb, S. M., Arnold, B. J., \& Cella, D. (2011). Spiritual Well-Being as a Component of Health-Related Quality of Life: The Functional Assessment of Chronic Illness Therapy-Spiritual WellBeing Scale (FACIT-Sp). Religions, 2(1), 77. https://doi.org/10.3390/rel2010077

Cella, D. F., Tulsky, D. S., Gray, G., Sarafian, B., Linn, E., Bonomi, A., .. . Brannon, J. (1993). The Functional Assessment of Cancer Therapy scale: development and validation of the general measure. Journal of Clinical Oncology, 11(3), 570-579. https:// doi.org/10.1200/jco.1993.11.3.570

Clay, K. S., Talley, C., \& Young, K. B. (2010). Exploring spiritual well-being among survivors of colorectal and lung cancer. Journal of Religion \& Spirituality in Social Work: Social Thought, 29(1), 14-32. https:// dx.doi.org/10.1080\%2F15426430903479247

Dahlia, D., Karim, D., \& Damanik, S. R. H. (2019). Gambaran fatigue pada pasien kanker post kemoterapi (An Overview of fatigue in post chemotherapy cancer patients). Jurnal Ners Indonesia, 10(1), 80-93. http://dx.doi. org/10.31258/jni.10.1.80-93

Dodd, M. J., Cho, M. H., Cooper, B. A., \& Miaskowski, C. (2010). The effect of symptom clusters on functional status and quality of life in women with breast cancer. European Journal of Oncology Nursing, 14(2), 101-110. http://dx.doi.org/10.1016/j. ejon.2009.09.005

Ellison, L. L. (2006). A review of the spiritual well-being scale. News Notes, 44(1), 1-10

Garssen, B., Uwland-Sikkema, N. F., \& Visser, A. (2015). How Spirituality Helps Cancer Patients with the Adjustment to their Disease. Journal of Religion and Health, 54(4), 1249-1265. https://doi.org/10.1007/ s10943-014-9864-9

Gilliam, L. A., \& St. Clair, D. K. (2011). Chemotherapy-induced weakness and fatigue in skeletal muscle: the role of oxidative stress. Antioxidants \& Redox Signaling, 
15(9), 2543-2563. https://doi.org/10.1089/ ars.2011.3965

Gomez, R., \& Fisher, J. W. (2003). Domains of spiritual well-being and development and validation of the Spiritual Well-Being Questionnaire. Personality and Individual Differences, 35(8), 1975-1991. http://dx.doi. org/10.1016/S0191-8869(03)00045-X

Hsieh, F.-C., Miao, N.-F., Tseng, I.-J., Chiu, H.-L., Kao, C.-C., Liu, D., . . . Chou, K.R. (2019). Effect of home-based music intervention versus ambient music on breast cancer survivors in the community: A feasibility study in Taiwan. European Journal of Cancer Care, 28(4). https://doi. org/10.1111/ecc.13064

Kandasamy, A., Chaturvedi, S., \& Desai, G. (2011). Spirituality, distress, depression, anxiety, and quality of life in patients with advanced cancer. Indian Journal of Cancer, 48(1), 55. https://doi.org/10.4103/0019$509 \times .75828$

Kinkead, B., Schettler, P. J., Larson, E. R., Carroll, D., Sharenko, M., Nettles, J., . . . Rapaport, M. H. (2018). Massage therapy decreases cancer-related fatigue: Results from a randomized early phase trial. Cancer, 124(3), 546-554. https://doi.org/10.1002/ cncr.31064

Komariah, M., Adriani, D., Indrayani, D., \& Gartika, N. (2020). Kebutuhan Spiritual pada Pasien dengan Kanker Stadium Akhir (Spiritual Needs of Patients with End-Stage Cancer). Jurnal Keperawatan Silampari, 4(1), 1-10. https://doi.org/10.31539/jks. v4i1.1221

Komariah, M., Hatthakit, U., \& Boonyoung, N. (2020). Impact of Islam-Based Caring Intervention on Spiritual Well-Being in Muslim Women with Breast Cancer Undergoing Chemotherapy. Religions, 11(7), 361. https://doi.org/10.3390/rel11070361

Komariah, M., \& Ibrahim, K. (2019). Training dan Coaching pada Pasien Kanker Payudara untuk Meningkatkan Ketaatan Melakukan Praktek Keagamaan (Training and Coaching for Breast Cancer Patients to Increase Adherence to doing Religious Practices). Media Karya Kesehatan, 2(2). https://doi.org/10.24198/mkk.v2i2.23024

Lestari, P., Nuraeni, A., \& Setyorini, D. (2018). Spiritual Distress In Breast Cancer Patients. Journal of Nursing Care, 1(2).

Lewis, S., Salins, N., Rao, M., \& Kadam, A. (2014). Spiritual well-being and its influence on fatigue in patients undergoing active cancer directed treatment: A correlational study. Journal of Cancer Research and Therapeutics, 10(3), 676-680. https://doi. org/10.4103/0973-1482.138125

Loh, K. Y. (2004). Spiritual distress in a terminally ill patient with breast cancer. International Journal of Palliative Nursing, 10(3), 131-132. https://doi/10.12968/ ijpn.2004.10.3.12466

Manning-Walsh, J. K. (2005). Psychospiritual Well-Being and Symptom Distress in Women With Breast Cancer. Oncol Nurs Forum, 32(3), 7-543. https://doi.org/10.1188/04.onf. e56-e65

Naraphong, W., Lane, A., Schafer, J., Whitmer, K., \& Wilson, B. R. A. (2015). Exercise intervention for fatigue-related symptoms in Thai women with breast cancer: A pilot study. Nursing \& Health Sciences, 17(1), 33-41. https://doi.org/10.1111/ nhs. 12124

National Comprehensive Cancer Network. (2009). NCCN Practice Guidelines in Oncology: Cancer Related Fatigue. Retrieved July 8, 2018, from https://www.ncen. org/patients/resources/life_with_cancer/ managing_symptoms/fatigue.aspx

Nuraeni, A., Ibrahim, K., \& Rizmadewi, H. (2013). Makna spiritualitas pada klien dengan sindrom koroner akut (Meaning of spirituality in clients with acute coronary syndrome). Jurnal Keperawatan Padjadjaran, 1(2). https://doi.org/10.24198/jkp.v1i2.55

Nuraeni, A., Nurhidayah, I., Hidayati, N., Sari, C. W. M., \& Mirwanti, R. (2015). Kebutuhan spiritual pada pasien kanker 
Maria Komariah: Correlation between Spiritual Well-Being and Level of Fatigue among Patients

(Spiritual needs in cancer patients). Jurnal Keperawatan Padjadjaran, 3(2). https://doi. org/10.24198/jkp.v3i2.101

Nurhasanah. (2014). Analisa kualitas hidup pasien kanker payudara pada setiap siklus kemoterapi di ruang Kemotherapy RSP [Analyze the Quality of Life of Breast Cancer Patients on Each Cycle of Chemotherapy at Chemotherapy Unit of the Teaching Hospital]. [Unpublished Master's thesis, Universitas Padjadjaran] Universitas Padjadjaran. Bandung, Indonesia.

Sari, N. P. W. P. (2019). Physical wellbeing in cervical and breast cancer survivors: a cross-sectional study in Surabaya, Indonesia. Indonesian Journal of Cancer, 12(3), 80-87. http://dx.doi.org/10.33371/ijoc.v12i3.614

Schmidt, M. E., Wiskemann, J., Armbrust, P., Schneeweiss, A., Ulrich, C. M., \& Steindorf, K. (2015). Effects of resistance exercise on fatigue and quality of life in breast cancer patients undergoing adjuvant chemotherapy: A randomized controlled trial. International Journal of Cancer, 137(2), 471-480. https:// doi.org/10.1002/ijc.29383

Suara, E., Mardiyono, M., \& Anggorowati, A. (2017). Relationship between demographic characteristics and spiritual wellbeing Among cancer survivors. Belitung Nursing Journal, 3(4), 405-411. https://doi.org/10.33546/ bnj. 74

Taylor, E. J. (1993). Factors associated with meaning in life among people with recurrent cancer. Oncology Nursing Forum, 20(9), 1399-405.

Villagomeza, L. R. (2005). Spiritual Distress in Adult Cancer Patients: Toward Conceptual
Clarity. Holistic Nursing Practice, 19(6), 285-294. https://doi.org/10.1097/00004650200511000-00010

Wahyuningsih, F. E., Sofro, M. A. U., \& Dwidiyanti, M. (2019). Spiritual Well being of Breast Cancer Patients Undergoing Chemotherapy through Mindfulness Based Spiritual. Media Keperawatan Indonesia, 2(3), 83-89. http://dx.doi.org/10.26714/ mki.2.3.2019.83-89

Wilding, C., Muir-Cochrane, E., \& May, E. (2006). Treading lightly: Spirituality issues in mental health nursing. International Journal of Mental Health Nursing, 15(2), 144-152. http://dx.doi.org/10.1111/j.14470349.2006.00414.x

Yellen, S. B., Cella, D. F., Webster, K., Blendowski, C., \& Kaplan, E. (1997). Measuring fatigue and other anemia-related symptoms with the Functional Assessment of Cancer Therapy (FACT) measurement system. Journal of Pain and Symptom Management, 13(2), 63-74. https://doi. org/10.1016/s0885-3924(96)00274-6

Zimmaro, L. A., Carson, J. W., Olsen, M. K., Sanders, L. L., Keefe, F. J., \& Porter, L. S. (2019). Greater mindfulness associated with lower pain, fatigue, and psychological distress in women with metastatic breast cancer. Psycho-Oncology, 29(2), 263-270. https://doi.org/10.1002/pon.5223 